
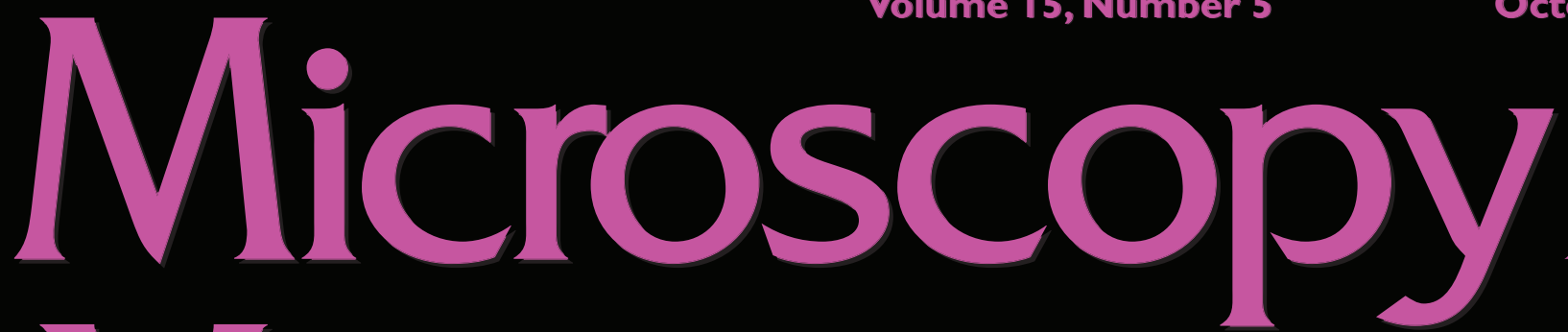

AND
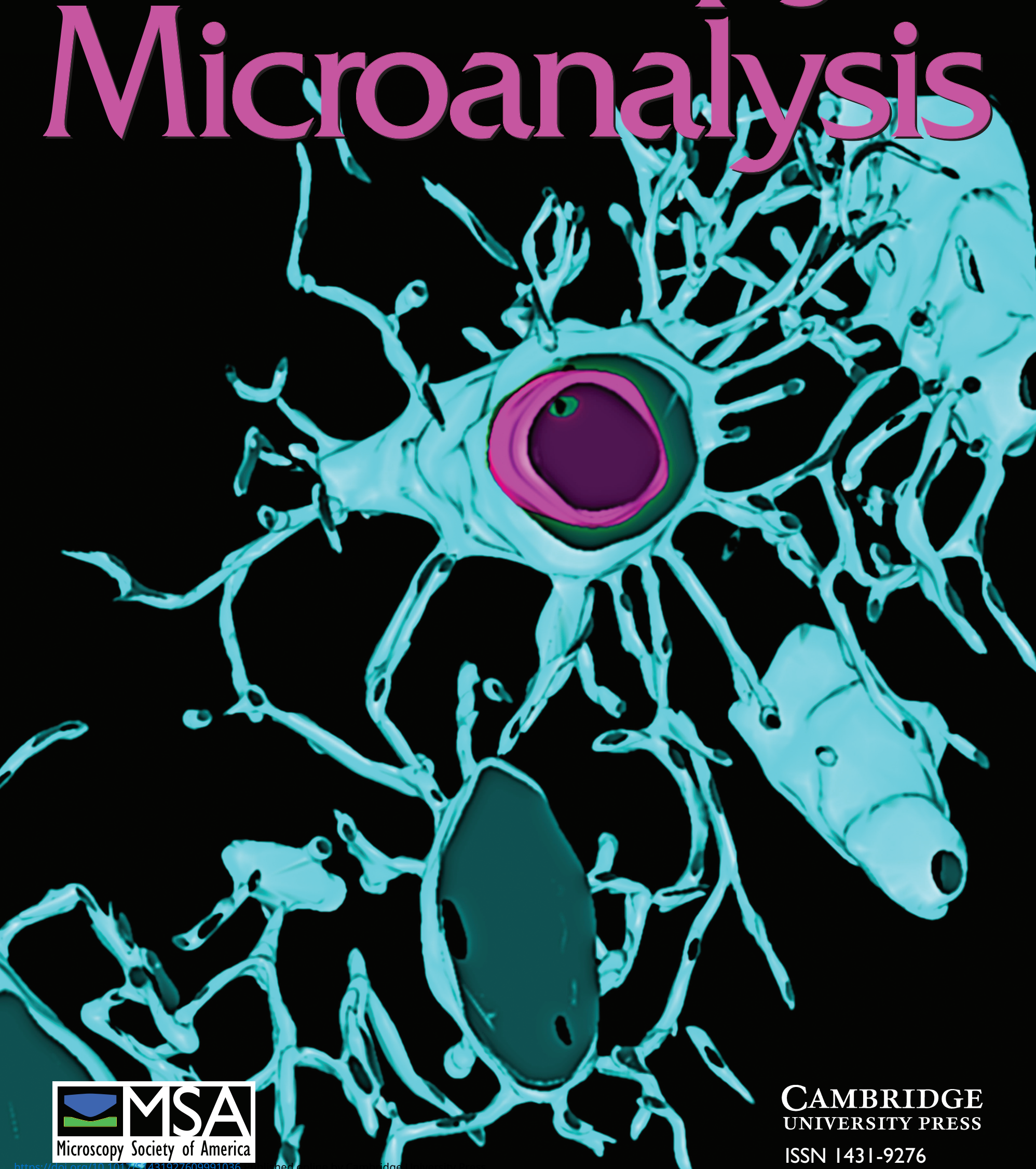


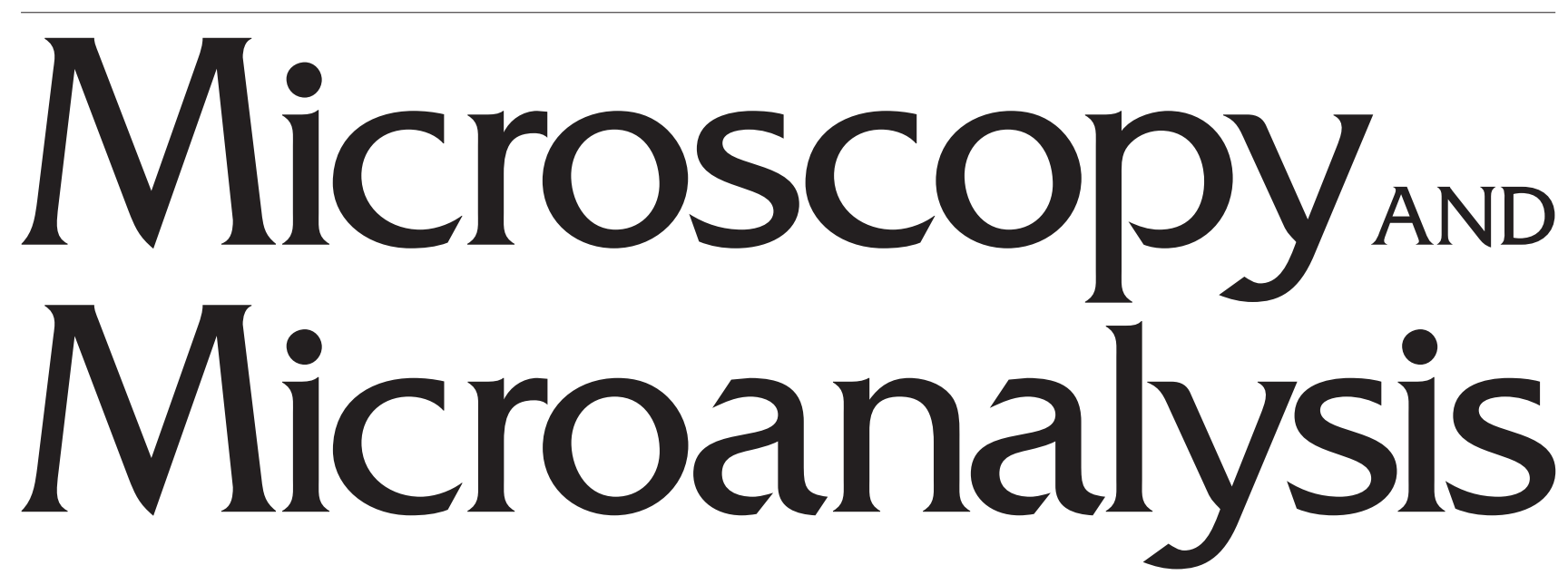

An International Journal for the Biological and Physical Sciences

THE OFFICIAL JOURNAL OF

PUBLISHED IN AFFILIATION WITH

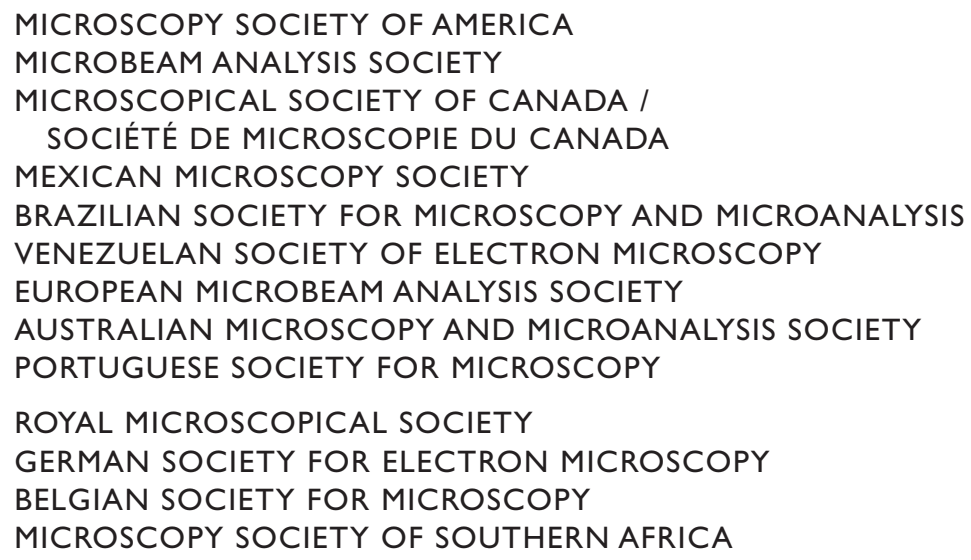

\section{Editor in Chief}

Editor, Biological Applications

Robert L. Price

Department of Cell and Developmental Biology and Anatomy

School of Medicine

University of South Carolina 6439 Garner's Ferry Road, Bldg. 1 B-60 Columbia, SC 29209

Phone: (803) 733-3392

Fax: (803) 733-3212

e-mail: Bob.Price@uscmed.sc.edu

Editor, Materials Applications David J. Smith

Department of Physics

School of Materials

Arizona State University

Tempe, Arizona 85287-1504

Phone: (480) 965-4540

Fax: (480) 965-9004

e-mail: david.smith@asu.edu

\section{Editor, Materials Applications}

Elizabeth Dickey

Materials Science and Engineering

Pennsylvania State University

223 MRL Building

University Park, PA 16802-7003

Phone: (814) 865-9067

Fax: (814) 863-8561

e-mail: ecd10@psu.edu
Editor, Light and Scanning Probe Microscopies

Brian Herman

Cellular and Structural Biology

University of Texas at San Antonio

7703 Floyd Curl Drive

San Antonio, Texas 78284-7762

Phone: (210) 567-3800

Fax: (210) 567-3803

e-mail: hermanb@uthscsa.edu

Editor, Biological Applications

Heide Schatten

Veterinary Pathobiology

University of Missouri-Columbia

1600 E. Rollins Street

Columbia, Missouri 65211-5030

Phone: (573) 882-2396

Fax: (573) 884-5414

e-mail: schattenh@missouri.edu

Editor, Microanalysis

John Mansfield

Electron Microbeam Analysis Lab

North Campus, 417 SRB

University of Michigan

2455 Hayward

Ann Arbor, MI 48109-2143

Phone: (734) 936-3352

Fax: (734) 763-2282

e-mail: jfmjfm@umich.edu
Special Issues and Reviews Editor Jay Jerome

Vanderbilt University Medical Center

Nashville, TN 37232

e-mail: jay.jerome@vanderbilt.edu

Book Review Editor

Cynthia S. Goldsmith

Centers for Disease Control

Atlanta, GA 30333

e-mail: csg1@cdc.gov

\section{Calendar Editor}

Nan Yao

Princeton University

Princeton, NJ 08540

e-mail: nyao@Princeton.edu

\section{Expo Editor}

Richard E. Edelmann

Miami University

Oxford, OH 45056

e-mail: edelmare@muohio.edu

\section{Proceedings Editor}

John Shields

University of Georgia

Athens, GA 30602

e-mail: jshields@cb.uga.edu 


\section{Editorial Board}

\author{
Ralph Albrecht \\ Barry Carter \\ Wah Chiu \\ Alwyn Eades \\ Mark Ellisman \\ Pratibha Gai \\ Marija Gajdardziska-Josifovska \\ Dale Johnson \\ Paul Kotula \\ William Landis \\ Eric Lifshin \\ Charles Lyman \\ Dale Newbury \\ Jean-Paul Revel \\ Conly Rieder \\ Phillip Russell \\ John Silcox \\ Nestor Zaluzec
}

University of Wisconsin, Madison, Wisconsin

University of Connecticut, Storrs, Connecticut

Baylor College of Medicine, Houston, Texas

Lehigh University, Bethlehem, Pennsylvania

University of California at San Diego, San Diego, California

University of York, United Kingdom

University of Wisconsin-Milwaukee, Milwaukee, Wisconsin

University of South Florida, Tampa, Florida

Sandia National Labs, Albuquerque, New Mexico

Northeastern Ohio Universities College of Medicine, Rootstown, Ohio

SUNY at Albany, Albany, New York

Lehigh University, Bethlehem, Pennsylvania

National Institute of Standards and Technology, Gaithersburg, Maryland

California Institute of Technology, Pasadena, California

Wadsworth Center, Albany, New York

Appalachian State University, Boone, North Carolina

Cornell University, Ithaca, New York

Argonne National Laboratory, Argonne, Illinois

\section{Editorial Board Representatives from Affiliated Societies}

Ian Anderson

Gema Gonzalez

Michael Robertson

Brendan Griffin

Guillermo Solorzano

Clive Walker

Miguel Yacaman

Henrique Almeida
NIST, Gaithersburg, Maryland (MAS)

Venezuelan Institute for Scientific Investigation (Venezuela)

Acadia University, Wolfville, Nova Scotia (Canada)

University of Western Australia (AMMS)

Pontificia Universidade Catolica, Rio de Janeiro (Brazil)

Institute for Transuranium Elements, Karlsruhe (EMAS)

Mexico Institute for Nuclear Research (Mexico)

Universidade do Porto (Portugal)

\section{Founding Editor}

Jean-Paul Revel

California Institute of Technology, Pasadena, California

\section{Previous Editors-in-Chief}

Dale Johnson

Charles Lyman
University of South Florida, Tampa, Florida

Lehigh University, Bethlehem, Pennsylvania

This journal is part of the Cambridge Journals Online service. Access to online tables of contents and article abstracts is available to all researchers at no cost. Access to full-text articles online is provided to those with online subscription. Online subscriptions must be activated. Once your subscription is activated, free access to past, present, and forthcoming articles is available at:

\section{Microscopy and Microanalysis website: journals.cambridge.org/MAM.}

Instructions for authors submitting manuscripts may be found at journals.cambridge.org/MAM. Select "Further Information" then select "Instructions for Contributors." An abbreviated version of these instructions will be published in the first issue (February) of each volume. 
Microscopy and Microanalysis publishes original research papers dealing with a broad range of topics in microscopy and microanalysis. These include articles describing new techniques or instrumentation and their applications, as well as papers in which established methods of microscopy or microanalysis are applied to important problems in the fields of biology or materials science. Microscopy and microanalysis are defined here in a broad sense, and include all current and developing approaches to the imaging and analysis of microstructure. The criteria for acceptance of manuscripts are the originality and significance of the research, the quality of the microscopy or microanalysis involved, and the interest for our readership.

Four types of communications are published in the Journal. Regular Articles are of substantial length and describe the findings of an original research project that satisfies the aims and scope of the Journal, described above. Review Articles summarize the current status of an important area within the aims and scope of the Journal. Letters to the Editor usually contain comments on recent articles that have appeared in the Journal. Book Reviews are also published, but these are solicited only through the Book Review Editor.

\section{Instructions for Contributors}

Instructions for authors contributing manuscripts may be found at http://mc.manuscriptcentral.com/mam under "Resources: Instructions and Forms." Authors may also visit http://www.journals.cambridge.org/ jid_MAM, select "Further Information," and then select "Instructions for Contributors." An abbreviated version of these instructions will be published in the first issue (February) of each volume.

\section{Copyright Information}

Submission of a manuscript implies: that the work described has not been published before (except in the form of an abstract or as part of a published lecture, review, or thesis); that it is not under consideration for publication elsewhere; that its publication has been approved by all coauthors, if any, as well as by the responsible authorities at the institute where the work has been carried out; that, if and when the manuscript is accepted for publication, the authors agree to automatic transfer of the copyright to the Microscopy Society of America; that the manuscript will not be published elsewhere in any language without the consent of the copyright holders; and that written permission of the copyright holder is obtained by the authors for material used from other copyrighted sources.

All articles published in this journal are protected by copyright, which covers the exclusive rights to reproduce and distribute the article (e.g., as offprints), as well as all translation rights. No material published in this journal may be reproduced photographically or stored on microfilm, in electronic data bases, video disks, etc., without first obtaining written permission from the publisher.

The use of general descriptive names, trade names, trademarks, etc., in this publication, even if not specifically identified, does not imply that these names lack protection by the relevant laws and regulation.

Authorization to photocopy items for internal or personal use, or the internal or personal use of specific clients, is granted by Cambridge University Press, provided that the appropriate fee is paid directly to Copyright Clearance Center, 222 Rosewood Drive, Danvers, MA 01923 , USA (Tel: (508) 750-8400), stating the ISSN (1431-9276), the volume, and the first and last page numbers of each article copied. The copyright owner's consent does not include copying for general distribution, promotion, new works, or resale. In these cases, specific written permission must first be obtained from the publisher.

\section{Disclaimer}

The Microscopy Society of America, the other societies stated, and Cambridge University Press cannot be held responsible for errors or for any consequences arising from the use of the information contained in this journal. The appearance of scientific reports and/or workshops, or any other material in Microscopy and Microanalysis does not constitute an endorsement or approval by The Microscopy Society of America of the findings, data, conclusions, recommendations, procedures, results, or any other aspect of the content of such articles. The appearance of advertising in Microscopy and Microanalysis does not constitute an endorsement or approval by The Microscopy Society of America of the quality or value of the products advertised or any of the claims, data, conclusions, recommendations, procedures, results, or any other information included in the advertisements.

While the advice and information in this journal is believed to be true and accurate at the date of its going to press, neither the authors, the editors, nor the publisher can accept any legal responsibility for any errors or omissions that may be made.

\section{Subscription Information}

Microscopy and Microanalysis is published bimonthly in February, April, June, August, October, and December by Cambridge University Press. Two supplements (Expo and Proceedings) are published in June and August.

Society Rates: Members of the Microscopy Society of America should contact the MSA Business Office for all subscription inquiries: Microscopy Society of America, Hachero Hill, Inc., 11260 Roger Bacon Drive, Suite 402, Reston, VA 20190, Tel.: (703) 964-1240, Ext. 14, E-mail: nicoleguy@mindspring.com, URL: www.msa.microscopy.org. Members of other affiliated societies should contact their respective society business offices for all subscription inquiries.

Subscription Rates: Institutions print and electronic: US \$920.00 in

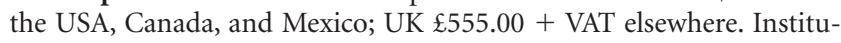
tions online only: US $\$ 760.00$ in the USA, Canada, and Mexico; UK $£ 460.00+$ VAT elsewhere. Institutions print only: US $\$ 830.00$ in the USA, Canada, and Mexico; UK $£ 500.00+$ VAT elsewhere. Individuals print and online: US $\$ 345.00$ in the USA, Canada, and Mexico; UK



USA, Canada, and Mexico: Subscribers in the USA, Canada, and Mexico should send their orders, with payment in US dollars or the equivalent value in Canadian dollars, to: Cambridge University Press, Customer Services Department (Journals), 100 Brook Hill Drive, West Nyack, NY 10994-2133, USA. Tel: (845) 353-7500. Fax: (845) 353-4141. Orders may be phoned direct (toll free): (800) 872-7423. E-mail: journals_subscriptions@cup.org.

Outside North America: Subscribers elsewhere should send their orders, with payment in sterling, to: Customer Services Department (Journals), Cambridge University Press, The Edinburgh Building, Shaftesbury Road, Cambridge, CB2 8RU, UK. Tel: +44 (0)1223 326070. Fax: +44 (0)1223 325150. E-mail: journals@cambridge.org

Change of address: Allow six weeks for all changes to become effective. All communications should include both old and new addresses (with postal codes) and should be accompanied by a mailing label from a recent issue. Society members should contact their respective society business offices to inform them of address changes.

Microform editions are available from: University Microfilms International, 300 North Zeeb Road, Ann Arbor, MI 48106, USA.

\section{Editorial Office}

Robert L. Price, Editor in Chief, Department of Cell and Developmental Biology and Anatomy, School of Medicine, University of South Carolina, 6439 Garner's Ferry Road, Bldg. 1 B-60, Columbia, SC 29209, USA; Tel: (803) 733-3392; Fax: (803) 733-3212; E-mail: Bob.Price@uscmed.sc.edu.

\section{Office of Publication}

Cambridge University Press, 32 Avenue of the Americas, New York, NY 10013-2473, USA; Tel: (212) 337-5000; Fax: (212) 337-5959.

\section{Advertising Sales \& Production}

M.J. Mrvica Associates, Inc., 2 West Taunton Avenue, Berlin, NJ 08009, USA; Tel: (856) 768-9360; Fax: (856) 753-0064.

(C) 2009 by Microscopy Society of America. Printed in the United States on acid-free paper. Periodicals postage paid at New York, NY, and additional mailing offices. Return postage guaranteed. Postmaster: Send address changes in the U.S.A. and Canada to Microscopy and Microanalysis, Subscription Department, Cambridge University Press, 100 Brook Hill Drive, West Nyack, NY 10994-2133. 


\section{Microscopy $_{\text {AND }}$ Microanalysis}

An International Journal for the Biological and Physical Sciences

Volume 15, Number 5

October 2009

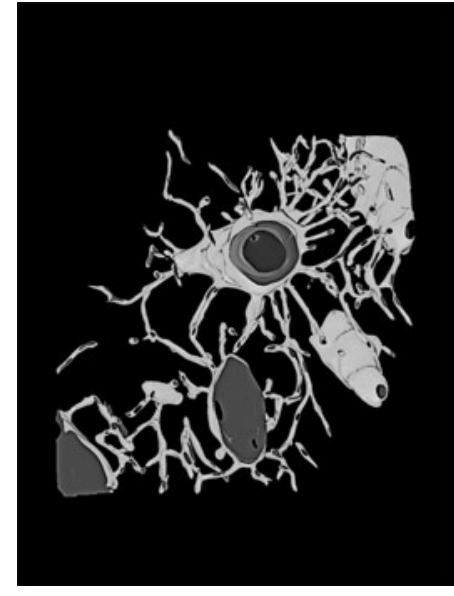

On the Cover: High-resolution tomography of osteocytes embedded in bone visualized by the Osaka ultra-high voltage electron microscopy. For further information please see the article by Kamioka et al. on p. 377.

\section{TOMOGRAPHY APPLICATIONS}

A Method for Observing Silver-Stained Osteocytes In Situ in 3- $\mu \mathrm{m}$ Sections Using Ultra-High Voltage Electron Microscopy Tomography

Hiroshi Kamioka, Sakhr A. Murshid, Yoshihito Ishihara, Naoko Kajimura,

Toshiaki Hasegawa, Ryoko Ando, Yasuyo Sugawara, Takashi Yamashiro, Akio Takaoka, and Teruko Takano-Yamamoto

X-Ray Microtomography Studies of Tannin-Derived Organic and Carbon Foams

G. Tondi, S. Blacher, A. Léonard, A. Pizzi, V. Fierro, J.M. Leban, and A. Celzard

Three-Dimensional X-Ray Imaging and Analysis of Fungi on and in Wood Jan Van den Bulcke, Matthieu Boone, Joris Van Acker, and Luc Van Hoorebeke

\section{Biological Applications}

An Innovative Triple Immunogold Labeling Method to Investigate the Hemopoietic Stem Cell Niche In Situ

Sarah L. Ellis, Brenda Williams, Stephen Asquith, Ivan Bertoncello, and Susan K. Nilsson

The Role of Interleukin-6 in the Formation of the Coronary Vasculature Indroneal Banerjee, John W. Fuseler, Colby A. Souders, Stephanie L.K. Bowers, and Troy A. Baudino

The Preimaginal Phases and Development of Pachycrepoideus vindemmiae (Hymenoptera, Pteromalidae) on Mediterranean Fruit Fly, Ceratitis capitata (Diptera, Tephritidae)

José Tormos, Francisco Beitia, Elias A. Böckmann, Josep D. Asís, and Severiano Fernández

\section{Materials Applications}

Compositional and Structural Study of a $\left(\mathrm{K}_{0.5} \mathrm{Na}_{0.5}\right) \mathrm{NbO}_{3}$ Single Crystal Prepared by Solid State Crystal Growth

Andreja Benčan, Elena Tchernychova, Matjaž Godec, John Fisher, and Marija Kosec

\section{INSTRUMENTATION AND SOFTWARE DEVEL OPMENT}

Characterizing the Two- and Three-Dimensional Resolution of an Improved Aberration-Corrected STEM

A.R. Lupini, A.Y. Borisevich, J.C. Idrobo, H.M. Christen, M. Biegalski, and

S.J. Pennycook

Spectrum Simulation in DTSA-II 
Contents continued

BOOK ReVIeW

Handbook of Cryo-Preparation Methods for Electron Microscopy. Edited by Annie Cavalier, Danielle Spehner, and Bruno M. Humber

469

Kent McDonald

Calendar of Meetings and Courses

471

https://doi.org/10.1017/S1431927609991036 Published online by Cambridge University Press 